Review

\title{
Review: Radionuclide Molecular Imaging Targeting HER2 in Breast Cancer with a Focus on Molecular Probes into Clinical Trials and Small Peptides
}

\author{
Shushan Ge ${ }^{1,2,+} \mathbb{D}$, Jihui Li ${ }^{1,+}$, Yu Yu ${ }^{1,+} \mathbb{D}$, Zhengguo Chen ${ }^{2}$, Yi Yang ${ }^{3}$, Liqing Zhu ${ }^{2}$, Shibiao Sang ${ }^{1, *}$ \\ and Shengming Deng $1,2,4, * \mathbb{D}$
}

1 Department of Nuclear Medicine, The First Affiliated Hospital of Soochow University, Suzhou 215006, China; geshushan0820@163.com (S.G.); valdes06@163.com (J.L.); yuyu333222111@126.com (Y.Y.)

2 Nuclear Medicine Laboratory of Mianyang Central Hospital, Mianyang 621099, China; maiwang342@163.com (Z.C.); z531343461@163.com (L.Z.)

3 Department of Nuclear Medicine, The Affiliated Suzhou Science \& Technology Town Hospital of Nanjing Medical University, Suzhou 215163, China; yaungyi@163.com

4 State Key Laboratory of Radiation Medicine and Protection, Soochow University, Suzhou 215123, China

* Correspondence: sshibiao@163.com (S.S.); dshming06@suda.edu.cn (S.D.)

+ These authors contributed equally to this work.

\section{check for}

updates

Citation: Ge, S.; Li, J.; Yu, Y.; Chen, Z.; Yang, Y.; Zhu, L.; Sang, S.; Deng, S. Review: Radionuclide Molecular Imaging Targeting HER2 in Breast Cancer with a Focus on Molecular Probes into Clinical Trials and Small Peptides. Molecules 2021, 26, 6482. https://doi.org/10.3390/ molecules 26216482

Academic Editors: Kazuma Ogawa and Alessandra Boschi

Received: 20 September 2021

Accepted: 26 October 2021

Published: 27 October 2021

Publisher's Note: MDPI stays neutral with regard to jurisdictional claims in published maps and institutional affiliations.

Copyright: (c) 2021 by the authors. Licensee MDPI, Basel, Switzerland. This article is an open access article distributed under the terms and conditions of the Creative Commons Attribution (CC BY) license (https:/ / creativecommons.org/licenses/by/ $4.0 /)$.

\begin{abstract}
As the most frequently occurring cancer worldwide, breast cancer (BC) is the leading cause of cancer-related death in women. The overexpression of HER2 (human epidermal growth factor receptor 2 ) is found in about $15 \%$ of $\mathrm{BC}$ patients, and it is often associated with a poor prognosis due to the effect on cell proliferation, migration, invasion, and survival. As a result of the heterogeneity of $\mathrm{BC}$, molecular imaging with HER2 probes can non-invasively, in real time, and quantitatively reflect the expression status of HER2 in tumors. This will provide a new approach for patients to choose treatment options and monitor treatment response. Furthermore, radionuclide molecular imaging has the potential of repetitive measurements, and it can help solve the problem of heterogeneous expression and conversion of HER2 status during disease progression or treatment. Different imaging probes of targeting proteins, such as monoclonal antibodies, antibody fragments, nanobodies, and affibodies, are currently in preclinical and clinical development. Moreover, in recent years, HER2specific peptides have been widely developed for molecular imaging techniques for HER2-positive cancers. This article summarized different types of molecular probes targeting HER2 used in current clinical applications and the developmental trend of some HER2-specific peptides.
\end{abstract}

Keywords: breast cancer; HER2; radionuclide molecular probes; molecular imaging; clinical trials

\section{Introduction}

Breast cancer (BC) has surpassed lung cancer as the most frequently occurring cancer worldwide, with 2.3 million new cases diagnosed in 2020 (11.7\% of all cancers), and BC ranks the fifth cause of cancer-related death overall and the leading cause of cancer death in women [1]. BC is a highly heterogeneous type of tumor [2], and it can be mainly categorized into four different subtypes: luminal A, luminal B, HER2 (human epidermal growth factor receptor 2)-positive, and triple-negative [3]. Currently, estrogen receptor $(\mathrm{ER})$, progesterone receptor (PR), and HER2 are three main clinical therapeutic targets for BC $[2,4,5]$. The overexpression of HER2 is found in about $15 \%$ of BC patients [6]. Furthermore, the overexpression of HER2 is often associated with a poor prognosis due to the effect on cell proliferation, migration, invasion, and survival [7-9].

Targeting HER2 with a range of anti-HER2 drugs has been successfully applied in clinical practice and significantly improved patient outcomes in both advanced and early disease settings [10]. However, there is increasing evidence of temporal and spatial heterogeneity in BC HER2 overexpression [11-13]. About $10.3 \%$ of patients will have inconsistent 
HER2 expression between primary breast tumors and distant metastases [13]. Therefore, accurate assessment of HER2 expression plays an essential role in cancer diagnosis and treatment.

The biopsy-based diagnosis has been proved to be clinically useful [11]. However, it is difficult to determine the heterogeneity and status discordance between primary and metastatic tissues using biopsy [14]. Moreover, bone metastases are frequently detected in $B C$ patients, and it is difficult to access their status by using biopsy [15]. Compared with biopsy, molecular imaging with anti-HER2 probes allows the non-invasive, wholebody assessment of tumor burden and may enable the selection of patients for HER2targeted therapy, dosage optimization, schedule of treatment, and assessment of response to anti-HER2 therapies [16-19]. This approach can reveal intertumoral or intratumoral heterogeneity as well as variations in HER2 expression over time.

In the present work, we focused on radionuclide molecular probes targeting HER2 and provided a comprehensive overview of different molecular probes used by the current clinical applications (Figure 1). Moreover, we also summarized the developmental trend of some HER2-specific peptides.

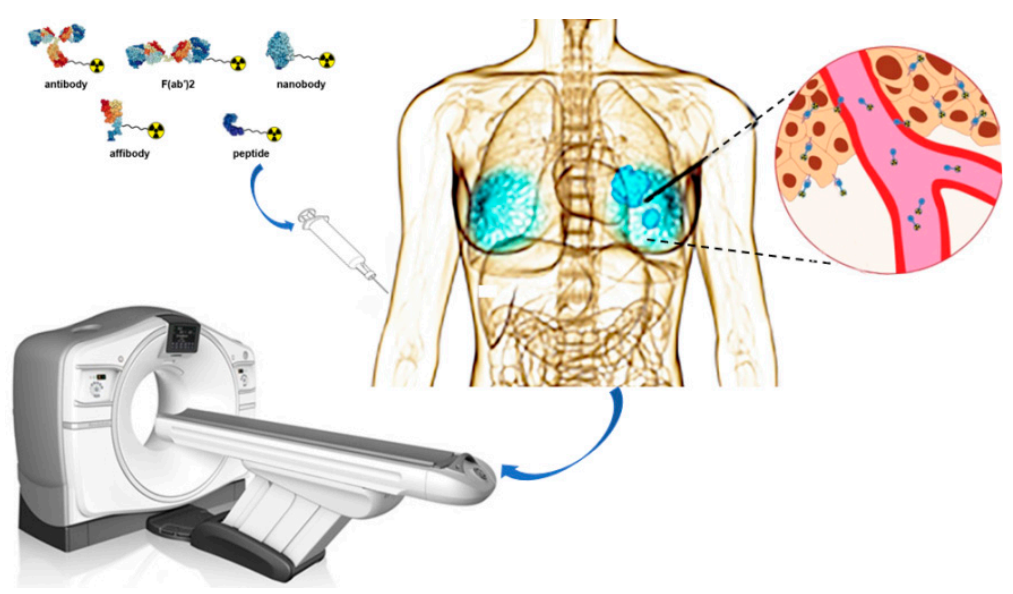

Figure 1. Schematic overview of nuclear imaging for Her2 positive BC. Ligands such as antibody, $\mathrm{F}\left(\mathrm{ab}^{\prime}\right) 2$ fragments, nanobody, affibody, and peptide can be coupled to a chelator. The chelator enables labeling with different radionuclides that can be applied for imaging purposes.

\section{Radionuclides}

Single-photon emission computed tomography (SPECT) and positron emission tomography (PET) are the basic radionuclide imaging modalities [20]. Table 1 lists the commonly used radionuclides for SPECT and PET. The nuclides ${ }^{99 \mathrm{~m}} \mathrm{Tc}$ and ${ }^{111} \mathrm{In}$ are widely used in SPECT. However, their poor diagnostic performance limits their clinical application. With the increasing popularity of cyclotrons, a variety of novel positron-emitting radionuclides (such as ${ }^{18} \mathrm{~F},{ }^{64} \mathrm{Cu},{ }^{68} \mathrm{Ga}$, and ${ }^{89} \mathrm{Zr}$ ) have been widely used in PET imaging. Compared with SPECT, PET has better sensitivity, spatial resolution, and quantization accuracy [21].

Table 1. Nuclides used in PET and SPECT imaging.

\begin{tabular}{ccc}
\hline Nuclide & $\mathbf{T}_{\mathbf{1 / 2}}$ & Production Method \\
\hline & Nuclides for SPECT imaging & \\
${ }^{99}{ }^{2} \mathrm{Tc}$ & $6.01 \mathrm{~h}$ & ${ }^{99} \mathrm{Mo} /{ }^{99 \mathrm{~m}} \mathrm{Tc}$ Generator \\
${ }^{123} \mathrm{I}$ & $13.3 \mathrm{~h}$ & Cyclotron \\
${ }^{111} \mathrm{In}$ & 2.8 days & Cyclotron \\
\hline \multirow{2}{*}{${ }^{13} \mathrm{~N}$} & Nuclides for PET imaging & \\
${ }^{11} \mathrm{C}$ & $9.97 \mathrm{~min}$ & Cyclotron \\
& $20.4 \mathrm{~min}$ & Cyclotron \\
\hline
\end{tabular}


Table 1. Cont.

\begin{tabular}{ccc}
\hline Nuclide & $\mathbf{T}_{\mathbf{1 / 2}}$ & Production Method \\
\hline${ }^{68} \mathrm{Ga}$ & $67.6 \mathrm{~min}$ & ${ }^{68} \mathrm{Ge} /{ }^{68} \mathrm{Ga}$ Generator \\
${ }^{18} \mathrm{~F}$ & $109.8 \mathrm{~min}$ & Cyclotron \\
${ }^{64} \mathrm{Cu}$ & $12.7 \mathrm{~h}$ & Cyclotron \\
${ }^{89} \mathrm{Zr}$ & $78.4 \mathrm{~h}$ & Cyclotron \\
${ }^{124} \mathrm{I}$ & $100 \mathrm{~h}$ & Cyclotron \\
\hline
\end{tabular}

\section{Radiolabeled HER2-Targeted Monoclonal Antibodies}

As the first humanized $\mathrm{mAb}$ against HER2, trastuzumab (Herceptin) is approved by the Food and Drug Administration (FDA) for HER2-positive BC, and it has been widely labeled by radionuclide, including ${ }^{111} \mathrm{In},{ }^{124} \mathrm{I},{ }^{64} \mathrm{Cu}$, and ${ }^{89} \mathrm{Zr}$ [22-25]. Of them, two initial clinical studies using ${ }^{111}$ In-DTPA-trastuzumab have reported the therapeutic effect and cardiotoxicity of patients with HER2-positive metastatic breast cancer (MBC) treated with trastuzumab $[22,26]$. Nonetheless, the poor resolution of SPECT may lead to a lower detection rate of HER2-positive tumors. However, trastuzumab labeled with positron nuclides ${ }^{89} \mathrm{Zr}$ and ${ }^{64} \mathrm{Cu}$ significantly improves the image quality. Several clinical studies (Table 2) have shown the value of ${ }^{89} \mathrm{Zr}$-Df-trastuzumab in detecting HER2-positive lesions and predicted the response to treatment with trastuzumab (Figure 2) as well as other types of treatment and trastuzumab-related toxicity [27-30]. However, Ulaner et al. have presented findings from a prospective clinical trial of ${ }^{89} \mathrm{Zr}$-trastuzumab PET/CT in a total of 20 patients with HER2-positive metastases and HER2-negative primary BC [27,28]. Three of these patients develop HER2-positive disease, which is confirmed by immunochemistry (IHC)/fluorescence in situ hybridization (FISH) (NCT02286843). A multi-center study (NCT01565200) consisting of $60 \mathrm{MBC}$ patients reported by Gebhart et al. [31] has investigated the association between the $\left.{ }^{89} \mathrm{Zr}\right]$-trastuzumab uptake and outcome after treatment with trastuzumab-emtansine (T-DM1). The study has shown that HER2-targeted imaging in combination with early metabolic response assessment is of great significance for judging the heterogeneity of $\mathrm{MBC}$ and for selecting patients who would benefit from T-DM1 treatment. Trastuzumab labeled with ${ }^{64} \mathrm{Cu}$ is an alternative that has also been tested in clinical practice [24,32]. A first-in-human feasibility study of ${ }^{64} \mathrm{Cu}$-DOTA-trastuzumab has demonstrated successful tumor uptake and visualization of HER2-positive primary BC and metastatic lesions in the brain [24]. The poor visualization of liver metastases due to high background uptake in the liver is a limiting factor for its clinical application. However, if cold trastuzumab is given in advance, high liver uptake can be reduced [33,34].

Table 2. The clinical trials of HER2-targeted monoclonal antibodies.

\begin{tabular}{ccccc}
\hline $\begin{array}{c}\text { Monoclonal } \\
\text { Antibodies }\end{array}$ & $\begin{array}{c}\text { Nuclide/Chelator } \\
\text { or Linker }\end{array}$ & Modality & Condition or Disease & Phase \\
\hline Trastuzumab & ${ }^{89} \mathrm{Zr-Df}$ & PET & HER2-Positive Solid Tumor & $\begin{array}{c}\text { Phase II } \\
\text { NCT04757090 }\end{array}$ \\
\hline Trastuzumab & ${ }^{9} \mathrm{Zr}$ & PET & Metastatic Breast Cancer & Phase II \\
NCT01832051 \\
\hline Trastuzumab & ${ }^{89} \mathrm{Zr}$-Df & PET /MRI & Breast Cancer & Early Phase I \\
\hline Trastuzumab & ${ }^{89} \mathrm{Zr}$-DFO & PET & Esophagogastric Cancer & NCT03321045 \\
\hline Trastuzumab & ${ }^{64} \mathrm{Cu}-\mathrm{DOTA}$ & PET & HER2 Positive Breast Carcinoma & Phase II \\
\hline
\end{tabular}


Table 2. Cont.

\begin{tabular}{|c|c|c|c|c|}
\hline $\begin{array}{l}\text { Monoclonal } \\
\text { Antibodies }\end{array}$ & $\begin{array}{l}\text { Nuclide/Chelator } \\
\text { or Linker }\end{array}$ & Modality & Condition or Disease & Phase \\
\hline Trastuzumab & ${ }^{64} \mathrm{Cu}$ & PET & HER2+ Metastatic Breast Cancer & $\begin{array}{c}\text { Phase I } \\
\text { NCT00605397 }\end{array}$ \\
\hline Trastuzumab & ${ }^{111}$ In-DTPA & SPECT & $\begin{array}{l}\text { Breast Cancer } \\
\text { Prostate Cancer } \\
\text { Lung Cancer } \\
\text { Colon Cancer }\end{array}$ & $\begin{array}{c}\text { Early Phase I } \\
\text { NCT01445054 }\end{array}$ \\
\hline Pertuzumab & ${ }^{89} \mathrm{Zr}-\mathrm{DFO}$ & PET & HER2-Positive cancer & $\begin{array}{c}\text { Phase I } \\
\text { NCT03109977 }\end{array}$ \\
\hline Pertuzumab & $\begin{array}{c}{ }^{89} \mathrm{Zr}-\mathrm{SS} \\
{ }^{89} \mathrm{Zr}\end{array}$ & PET & $\begin{array}{l}\text { HER-2 Positive Malignant Carcinoma } \\
\text { of Breast } \\
\text { HER2-Positive Metastatic Breast } \\
\text { Cancer }\end{array}$ & $\begin{array}{c}\text { Phase I } \\
\text { NCT04692831 }\end{array}$ \\
\hline Pertuzumab & ${ }^{111} \mathrm{In}$ & SPECT & Breast Cancer & $\begin{array}{c}\text { Phase I } \\
\text { NCT01805908 }\end{array}$ \\
\hline
\end{tabular}

\section{A}

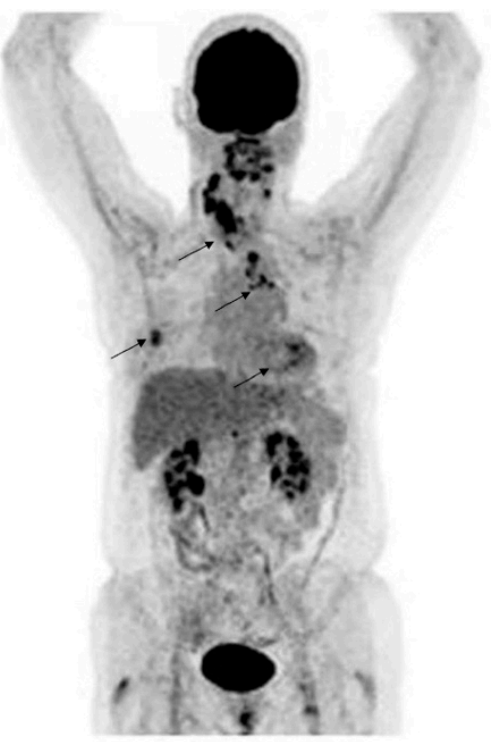

B

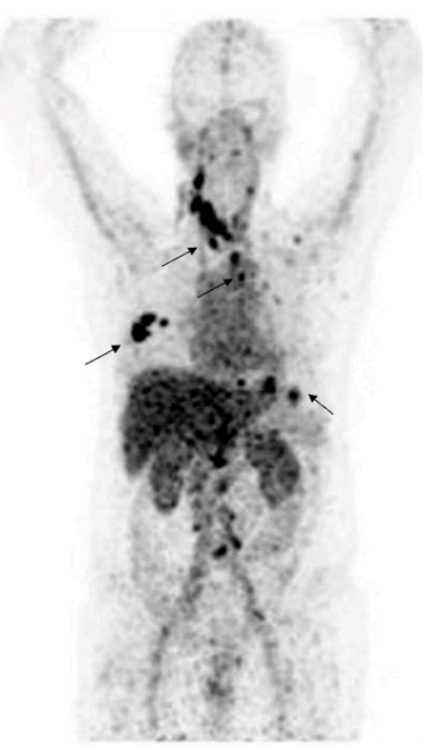

Figure 2. Representative molecular PET images of a patient with HER2-positive BC were visualized by ${ }^{18}$ F-FDG (A) and HER2 (B) imaging with ${ }^{89}$ Zr-trastuzumab. Images are reproduced with permission from [30].

In addition to trastuzumab, pertuzumab is another FDA-approved mAb targeting HER2. In nuclear medicine, this humanized $\mathrm{mAb}$ has been labeled with a variety of radiometals [35-39] and proposed to be used as the imaging agent during monotherapy with trastuzumab [40], since its binding site of HER2 (domain II) is different from trastuzumab (domain IV). The first-in-human trial has demonstrated that ${ }^{89} \mathrm{Zr}$-pertuzumab is a clinically valuable HER2-targeted imaging agent for MBC patients [37]. In addition, a prospective clinical trial (NCT02286843) has demonstrated that ${ }^{89} \mathrm{Zr}$-pertuzumab PET/CT helps identify patients with HER2-positive metastases and HER2-negative primary BC [36].

\section{Radiolabeled HER2-Targeted Antibody Fragments}

The Fab and $\mathrm{F}\left(\mathrm{ab}^{\prime}\right) 2$ fragments of anti-HER2 antibodies, trastuzumab, and pertuzumab labeled with several different radionuclides have been evaluated for imaging in preclinical models [41-44]. However, all tested probes have a common feature that HER2-positive tumors can be clearly imaged at $24 \mathrm{~h}$ after injection. As reported by Smith-Jones [41], 
${ }^{111}$ In-DOTA-(Fab') 2 provides a tumor-to-blood ratio of 10 already at $24 \mathrm{~h}$, and the tumor uptake of [111 In]-DOTA-(Fab')2 ( 20\% ID/g) is much lower compared with [ $\left.{ }^{111} \mathrm{In}\right]-D O T A-$ trastuzumab $(\approx 50 \% \mathrm{ID} / \mathrm{g})$. This finding reflects the general feature of antibody fragments, showing lower tumor uptake compared with parental antibodies. Reilly et al. [43] have reported that ${ }^{64} \mathrm{Cu}-\mathrm{NOTA}-\mathrm{F}\left(\mathrm{ab}^{\prime}\right) 2$-pertuzumab can detect changes in the expression of HER2 in response to trastuzumab while delivering a lower total body radiation dose compared with ${ }^{111}$ In-labeled pertuzumab. Beylergil et al. [44] have reported a clinical study on the diagnostic utility of ${ }^{68} \mathrm{Ga}-\mathrm{DOTA}-\mathrm{F}\left(\mathrm{ab}^{\prime}\right) 2$-trastuzumab in $15 \mathrm{BC}$ patients (NCT00613847). The results of clinical evaluations are hardly encouraging, since only $4 / 8$ patients with HER2-positive BC are detected.

The long waiting time for imaging of intact radiolabeled antibodies can be solved by using radiolabeled $\left(\mathrm{Fab}^{\prime}\right) 2$ and Fab fragments. However, similar to intact antibodies, the contrast of the main metastatic sites of radiometal-labeled fragments still remains the main problem limiting its clinical application.

\section{Radiolabeled HER2-Targeted Nanobodies}

Due to the small size and high affinity, nanobodies can penetrate tumor tissues and bind antigens with high specificity, making them a suitable therapeutic and diagnostic tool [45] (Table 3). As an sdAb developed against HER2, 2Rs15d has shown excellent targeting of HER2 in both preclinical settings [46] and clinical settings [47]. A phase I study of ${ }^{68} \mathrm{Ga}-\mathrm{NOTA}-2 \mathrm{Rs} 15 \mathrm{~d}$ reported by Keyaerts et al. [47] has shown that its biodistribution is favorable with a fast blood clearance. The primary lesions of $\mathrm{BC}$ patients show a wide uptake of $0.7-11.8$, while significant uptake is observed in most metastatic lesions, indicating that ${ }^{68} \mathrm{Ga}-\mathrm{NOTA}-2 \mathrm{Rs} 15 \mathrm{~d}$ may not be suitable to be used to evaluate the expression of HER2 in primary BC lesions. Currently, a phase II clinical trial (NCT03331601) to evaluate its potential for detecting brain metastases in BC patients and a phase II clinical trial (NCT03924466) to evaluate the correlation between image-based HER2 quantification in the uptake of ${ }^{68} \mathrm{Ga}-\mathrm{NOTA}-2 \mathrm{Rs} 15 \mathrm{~d}$ in local or distant metastasis in BC patients are all in progress.

Table 3. The clinical trials of HER2-targeted nanobodies.

\begin{tabular}{|c|c|c|c|c|}
\hline Nanobodies & $\begin{array}{c}\text { Nuclide/Chelator or } \\
\text { Linker }\end{array}$ & Modality & Condition or Disease & Phase \\
\hline 2Rs15d & ${ }^{68} \mathrm{Ga}-\mathrm{NOTA}$ & PET & $\begin{array}{c}\text { Breast Carcinoma } \\
\text { Brain Metastasis of Breast } \\
\text { Carcinoma }\end{array}$ & $\begin{array}{c}\text { Phase II } \\
\text { NCT03331601, } \\
\text { NCT03924466 }\end{array}$ \\
\hline 2Rs15d & ${ }^{131} \mathrm{I}$ & SPECT & Breast Cancer & $\begin{array}{c}\text { Phase I } \\
\text { NCT02683083 }\end{array}$ \\
\hline NM-02 & ${ }^{99 \mathrm{~m}} \mathrm{Tc}$ & SPECT & Breast Cancer & $\begin{array}{c}\text { Early Phase I } \\
\text { NCT04040686 }\end{array}$ \\
\hline MM-302 & ${ }^{64} \mathrm{Cu}$ & PET & $\begin{array}{c}\text { Advanced HER2+ Cancers } \\
\text { with Brain Mets }\end{array}$ & $\begin{array}{r}\text { Early Phase I } \\
\text { NCT02735798 }\end{array}$ \\
\hline
\end{tabular}

What is more, nanobody $2 \mathrm{Rs} 15 \mathrm{~d}$ is also labeled with various nuclides, such as ${ }^{18} \mathrm{~F}$, ${ }^{99 \mathrm{~m}} \mathrm{Tc},{ }^{131} \mathrm{I}$, and ${ }^{177} \mathrm{Lu}$. Similar to ${ }^{68} \mathrm{Ga}-\mathrm{NOTA}-2 \mathrm{Rs} 15 \mathrm{~d},{ }^{99 \mathrm{~m}} \mathrm{Tc}-2 \mathrm{Rs} 15 \mathrm{~d}[48]$ and $\left[{ }^{18} \mathrm{~F}\right] \mathrm{RL}-\mathrm{II}-$ 2Rs15d [49] show high tumor uptake, rapid blood clearance, low accumulation in nontarget organs other than the kidneys, and a high tumor to background ratio. Furthermore, the PET imaging of ${ }^{18} \mathrm{~F}$-labeled $2 \mathrm{Rs} 15 \mathrm{~d}$ with different chelators $[49,50]$ shows significant tumor uptake and substantially lower renal uptake.

$2 \mathrm{Rs} 15 \mathrm{~d}$ is also labeled with a therapeutic radionuclide. In the preclinical study, ${ }^{131} \mathrm{I}-$ SGMIB-2Rs15d [51] and ${ }^{177}$ Lu-DTPA-2Rs15d [52] have been shown to significantly prolong median survival. A phase I clinical trial (NCT02683083) of ${ }^{131}$ I-SGMIB-2Rs15d in healthy volunteers and patients with HER2-positive BC shows a high tumor to background ra- 
tio, rapid blood clearance, and elimination of unbound nanobodies via the kidney after intravenous administration.

In addition, two single-domain antibodies (MM-302 and NM-02) have been labeled and entered clinical studies. The tumor accumulation of ${ }^{64} \mathrm{Cu}-\mathrm{MM}-302$ ranges from 0.52 to $18.5 \% \mathrm{ID} / \mathrm{kg}$ after $24-48 \mathrm{~h}$, including deposition in bone and brain lesions [53]. It is worth noting that significant background absorption of ${ }^{64} \mathrm{Cu}-\mathrm{MM}-302$ is observed in the liver and spleen. Currently, the phase I clinical trial of ${ }^{64} \mathrm{Cu}-\mathrm{MM}-302$ (NCT02735798) has been terminated. At present, no results have been reported for another ${ }^{99 \mathrm{~m}} \mathrm{TC}$-labeled nanobody NM-02 that has entered the clinical early phase I study (NCT04040686).

\section{Radiolabeled HER2-Targeted Affibodies}

Affibody [54] is a triple helix structure composed of 58 amino acids, which is also called an "artificial antibody". In contrast to antibodies, the smaller affibody molecules have relatively fast uptake and clearance rates [55]. In addition, the affibody molecules have high affinity and stability, and thus, they are very well suited for molecular imaging (Table 4). The anti-HER2 affibody molecule ZHER2:342 and its derivatives are second-generation HER2-targeted affibodies, which are the most studied affibody imaging probes radiolabeled with different nuclides [56-58]. ABY-002 (DOTA ZHER2:342 pep2) is a derivative of ZHER2:342 with a DOTA coupled to its NH2 terminus. The first clinical trial of the radiolabeled HER2-targeted affibody ABY-002 labeled with ${ }^{111}$ In and ${ }^{68} \mathrm{Ga}$ has demonstrated their potential for visualizing HER2-expressing metastatic lesions in BC patients [59].

Table 4. The clinical trials of HER2-targeted affibodies.

\begin{tabular}{ccccc}
\hline Affibodies & $\begin{array}{c}\text { Nuclide/Chelator } \\
\text { or Linker }\end{array}$ & Modality & $\begin{array}{c}\text { Condition or } \\
\text { Disease }\end{array}$ & Phase \\
\hline ABY-025 & ${ }^{68} \mathrm{Ga}$ & PET & $\begin{array}{c}\text { HER2-Positive } \\
\text { Breast Cancer, } \\
\text { Breast Cancer }\end{array}$ & $\begin{array}{c}\text { Phase I/II } \\
\text { NCT02095210 } \\
\text { NCT01858116 }\end{array}$ \\
\hline ABY-025 & ${ }^{111} \mathrm{In}$ & SPECT & Breast Cancer & $\begin{array}{c}\text { Phase I/II } \\
\text { NCT01216033 }\end{array}$ \\
\hline ABH2 & $99 \mathrm{~m} \mathrm{Tc}$ & SPECT & Breast Cancer & $\begin{array}{c}\text { Early Phase I } \\
\text { NCT03546478 }\end{array}$ \\
\hline HPark2 & $99 \mathrm{~m} \mathrm{Tc}$ & SPECT & Breast Cancer & $\begin{array}{c}\text { Early Phase I } \\
\text { NCT04267900 }\end{array}$ \\
\hline GE-226 & ${ }^{18} \mathrm{~F}$ & PET & Breast Cancer & NCT03827317 \\
\hline ADAPT6 & $99 \mathrm{~m} \mathrm{Tc}$ & SPECT & Breast Cancer & NCT03991260 \\
\hline
\end{tabular}

As another HER2-targeted affibody, ABY-025 (ZHER2:2891) has been investigated in clinical trials. The ${ }^{111}$ In-ABY-025 [60] has demonstrated favorable biodistribution, safety, and tumor-targeting potential in patients with HER2-expressing MBC (NCT01216033). It is worth noting that one patient with MBC and HER2-positive primary tumor imaging by ${ }^{111}$ In-ABY-025 shows a HER2-negative status of the metastases, as confirmed by IHC. Two other clinical trials (NCT02095210 and NCT01858116) have studied the effects of two different doses of ${ }^{68} \mathrm{Ga}-\mathrm{ABY}-025(100 \mu \mathrm{g}$ or $500 \mu \mathrm{g}$ ) on tumor uptake. The PET image shows that the injection of $500 \mu \mathrm{g}{ }^{68} \mathrm{Ga}-\mathrm{ABY}-025$ leads to a better specificity after 2 to $4 \mathrm{~h}$ and allows the differentiation of metastases with HER2 expression levels of $3+$ and $2+[61,62] .{ }^{68} \mathrm{Ga}-$ ABY-025 is currently being investigated in further clinical research. Furthermore, ABY-025 is also labeled with ${ }^{18} \mathrm{~F}$ by using three methods (such as ${ }^{18} \mathrm{~F}-\mathrm{SiFA},{ }^{18} \mathrm{~F}-\mathrm{AlF}-\mathrm{NOTA}$, and ${ }^{18} \mathrm{~F}$ FBA) [63]. Glaser et al. [64] have found that ${ }^{18}$ F-FBA-ZHER2:2891 (GE226) with enhanced pharmacokinetic characteristics can differentiate tumors with different expression levels of HER2 by imaging. The efficacy of $\left[{ }^{18} \mathrm{~F}\right] \mathrm{GE}-226$ in determining the expression of HER2 in MBC patients is being investigated (NCT03827317). No results have yet been reported for 
this study yet. Another ${ }^{99 \mathrm{~m}} \mathrm{Tc}-$ labeled affibody (HPArk2) is also being investigated in an open-label phase I clinical trial, while no results have been published (NCT04267900).

Hober et al. have reported the development of an affibody ADAPT6 that binds HER2 [65]. The pharmacologic studies have demonstrated that ${ }^{111} \mathrm{In} /{ }^{68} \mathrm{Ga}-\mathrm{DOTA}-(\mathrm{HE}) 3-$ ADAPT6 is specifically taken up by HER2+ tumors, with a high tumor-to-normal tissue ratio in mice xenograft tumor models. Furthermore, they have evaluated the effects of the commonly used macrocyclic chelators NOTA, NODAGA, DOTA, and DOTAGA on the biodistribution characteristics of ADAPT6 [66]. It has been concluded that ${ }^{111} \mathrm{In}$ (HE)3DANS-ADAPT6-GSSC-DOTA is best for SPECT imaging, while ${ }^{68} \mathrm{Ga}-(\mathrm{HE}) 3 \mathrm{DANS}-$ ADAPT6-GSSC-NODAGA is best for PET imaging. The phase I clinical study has shown that ${ }^{99 \mathrm{~m}} \mathrm{Tc}-\mathrm{ADAPT} 6$ is safe, and a protein dose of $500 \mu \mathrm{g}$ can be used to distinguish tumors with high or low expression of HER2 as early as $2 \mathrm{~h}$ after injection [67]. The above-mentioned results indicate that ADAPT6 is a potential molecular imaging probe.

\section{Radiolabeled HER2-Targeted Peptides}

Peptides have many favorable characteristics suitable for the development of imaging agents. First of all, unlabeled small molecule precursors have the advantages of definite chemical structure, flexible modification space, controllable pharmacokinetic properties, non-immunogenicity, and ease of synthesis commonly involving solid-phase peptide synthesis. Secondly, radionuclide-labeled peptides have higher tissue penetration and faster circulation time in the blood [68,69]. Therefore, imaging of HER2-expressing tumors with radionuclide peptides can lead to quicker imaging time and provide accurate assessment results for treatment based on the expression of HER2. Many peptides have shown promising application value in the detection of HER2 expression in BC (Table 5).

Table 5. Specific HER2-targeted peptides.

\begin{tabular}{ccccc}
\hline Peptide & Labeling Strategy & Modality & Kd (nM) & Reference \\
\hline KCCYSL & ${ }^{111}$ In-DOTA-GSG & SPECT & $295 \pm 56$ & {$[64]$} \\
MEGPSKCCYSLALASH & ${ }^{111}$ In-DOTA & SPECT & $236 \pm 83$ & {$[67]$} \\
GTKSKCCYSLRRSS & ${ }^{111}$ In-DOTA & SPECT & $289 \pm 13$ & {$[67]$} \\
CGGGLTVSPWY & $99 \mathrm{~m}$ Tc & SPECT & $4.3 \pm 0.8$ & {$[69]$} \\
CSSSLTVSPWY & $99 \mathrm{~m}$ Tc & SPECT & $33.9 \pm 9.7$ & {$[69]$} \\
SSSLTVPWY & $99 \mathrm{~m}$ Tc-HYNIC & SPECT & $2.6 \pm 0.5$ & {$[70]$} \\
SSSLTVPWY & ${ }^{99} \mathrm{~m}$ Tc-HYNIC-EDDA/tricine & SPECT & $3.3 \pm 1.0$ & {$[71]$} \\
SSSLTVPWY & 68 Ga-DOTA & PET & $2.5 \pm 0.6$ & {$[72]$} \\
FCGDFYACYMDV & ${ }^{111}$ In-DTPA-peptide-PEG & SPECT & 300 & {$[73]$} \\
H6F & $99 \mathrm{~m}$ Tc-HYNIC & SPECT & $7.48 \pm 3.26$ & {$[74]$} \\
H10F & $99 \mathrm{~m}$ Tc-HYNIC & SPECT & NA & {$[75]$} \\
A9 & ${ }^{111}$ In-DTPA & SPECT & $4.9 / 103$ & {$[76]$} \\
\hline
\end{tabular}

\subsection{KCCYSL-Based Peptides}

One of the most studied peptides specific for HER2 is the KCCYSL peptide or peptides with KCCYSL incorporated into the sequence. The peptide KCCYSL is first found by Karasseva et al. [70] from a random six-amino acid peptide bacteriophage display library and shows a strong affinity to HER2. Then, it has been evaluated in multiple studies both in vitro and in vivo. KCCYSL is radiolabeled with ${ }^{111} \mathrm{In}$ and ${ }^{64} \mathrm{Cu}$ by Kumar et al. for the imaging of HER2-positive tumors [71,77]. The cell-binding experiments have shown that the radiolabeled peptides ${ }^{111} \mathrm{In}-\mathrm{DOTA}(\mathrm{GSG})-\mathrm{KCCYSL}$ and ${ }^{64} \mathrm{Cu}-(\mathrm{GSG})-\mathrm{KCCYSL}$ can specifically bind to MDA-MB-435 cells (HER2+), while the scrambled peptide ${ }^{111}$ In-DOTA(GSG)KYLCSC peptide does not bind to MDA-MB-435 cells. In vivo studies have confirmed that imaging with radiolabeled peptides can specifically identify HER2+ tumors and HER2- in SCID mice at $2 \mathrm{~h}$ after injection.

Larimer et al. [72] have developed two peptides, MEGPSKCCYSLALASH (1-D03) and GTKSKCCYSLRRSS (3-G03), which have higher binding affinity compared with the 
original peptide. Each peptide is radiolabeled with ${ }^{111}$ In for further studies. Among them, the biodistribution of ${ }^{111}$ In-DOTA-1-D03 shows that the ratio of tumor to blood after $2 \mathrm{~h}$ is about 6 . The SPECT imaging shows that radiolabeled peptides can clearly image HER2+ tumors and show specific binding.

The KCCYSL peptides show great potential as a targeting agent for the development of HER2. Radiolabeled versions of this peptide have been shown to have suitable imaging capabilities with SPECT and are hopefully developed as a PET imaging agent.

\subsection{LTVSPWY-Based Peptides}

Shadidi et al. [73] have used another phage display biopanning procedure that results in the discovery of another HER2-specific peptide (LTVSPWY). Several peptides with LTVSPWY incorporated into the sequence have been radiolabeled by ${ }^{99 \mathrm{~m}} \mathrm{Tc}$ and $68 \mathrm{Ga}$ for imaging studies of HER2-positive tumors. Sabahnoo et al. [78] have used ${ }^{99 \mathrm{~m}}$ Tc to label two peptides with core LTVSPWY and a cysteine-based ligand (CGGG or CSSS). The ${ }^{99 \mathrm{~m} T \mathrm{~T}-}$ CGGG-LTVSPWY and ${ }^{99 m}$ Tc-CSSS-LTVSPWY peptides show significantly higher binding to SKOV-3 (HER2+) cells compared with A549 and MCF-7 (HER2-) cells. The competitive binding of trastuzumab has confirmed that these peptides have similar binding sites as trastuzumab. In in vivo studies, mice bearing SKOV-3 xenografts are injected with each peptide to determine the tumor\%ID/g after 1 and $4 \mathrm{~h}$. The ${ }^{99 \mathrm{~m}} \mathrm{Tc}-\mathrm{CGGG-LTVSPWY}$ has a tumor $\% \mathrm{ID} / \mathrm{g}$ of $3.84 \pm 2.5$ and $2.44 \pm 1.1 \% \mathrm{ID} / \mathrm{g}$ at 1 and $4 \mathrm{~h}$, respectively. The ${ }^{99 \mathrm{~m}} \mathrm{Tc}-\mathrm{CSSS}-$ LTVSPWY peptide has similar values of $4.98 \pm 4.8$ and $2.26 \pm 2.1 \% \mathrm{ID} / \mathrm{g}$, respectively, at the corresponding time points.

The team of Hosseinimehr has conducted multiple studies on the same core peptide $[74,75,79,80]$. They have used multiple nuclides to label the peptide with the addition of a new chelator and linker system, SSSLTVPWY. It has been shown that ${ }^{99 \mathrm{~m}} \mathrm{Tc}-\mathrm{HYNIC}-$ (Ser) 3-LTVPWY can specifically target HER2+ tumors, including SKOV-3 ovarian cancer, at $4 \mathrm{~h}$ post-injection, while U-87 MG glioma-based tumors can be visualized after just at $1 \mathrm{~h}$ post-injection. In addition, they have also used the EDDA/tricine mixture as a co-ligand to label HYNIC-SSSLTVSPWY with ${ }^{99 \mathrm{~m}}$ Tc. In vivo experiments have shown that ${ }^{99 \mathrm{~m}} \mathrm{Tc}-\mathrm{HYNIC}$-(EDDA/tricine)-peptide exhibits noticeable tumor uptake compared with non-target organs after $4 \mathrm{~h}$. However, the ratios of the tumor to blood, or the tumor to muscle for ${ }^{99 \mathrm{~m}} \mathrm{Tc}-\mathrm{HYNIC}$-(Ser)3-LTVPWY are 1.32 and 2.65, respectively, and ${ }^{99 \mathrm{~m}} \mathrm{Tc}-$ HYNIC(EDDA/tricine)-(Ser)3-LTVSPWY with higher ratios (6.93 and 4.05 respectively) results in better pharmacokinetic modification. The positron nuclide ${ }^{68} \mathrm{Ga}$ is also used to label SSSLTVSPWY. The PET imaging experiments exhibit a capacity of ${ }^{68} \mathrm{Ga}$-DOTA-(Ser)3LTVSPWY for imaging the HER2-positive tumors in nude mice with high contrast.

\subsection{The Peptide AHNP}

The peptide AHNP is obtained by analyzing the CDR3 loop of the heavy chain of trastuzumab that binds to the antigen through a structure-based method by Park et al. [76]. The AHNP has an amino acid sequence of FCGDFYACYMDV with a binding affinity for HER2 of $395 \mathrm{nM}$. Guan Siao-Syun et al. [81] have used ${ }^{111}$ In to label AHNP-PEG with the chelator DTPA and performed potential imaging in patients with HER2-positive gastric cancer. In vivo imaging experiments in xenografts mice induced by NCI-N87 have shown that ${ }^{111}$ In-DTPA-AHNP-PEG can clearly identify HER2-positive gastric tumors at 1, 4, 24, and $48 \mathrm{~h}$.

\subsection{The Peptides H6F and H1OF}

The H6F(YLFFVFER) [82] and H10F(KLRLEWNR) [83] peptides reported by the group of Wang [84] are discovered by an efficient peptide screening strategy based on in situ single-bead sequencing microarray, and both peptides show high binding and selectivity to HER2. They have used ${ }^{99 \mathrm{~m}} \mathrm{Tc}$ to label these two peptides with the chelator HYNIC. ${ }^{99 \mathrm{~m}}$ Tc-HYNIC-H6F and ${ }^{99 \mathrm{~m}}$ Tc-HYNIC-H10F display excellent HER2-binding specificity both in vitro and in vivo. SPECT/CT imaging with ${ }^{99 \mathrm{~m}} \mathrm{Tc}-\mathrm{HYNIC}-\mathrm{H} 6 \mathrm{~F} /{ }^{99 \mathrm{~m}} \mathrm{Tc}-\mathrm{HYNIC}-$ 
H10F in MDA-MB-453, SK-BR3, and MDA-MB-231 xenograft mice model reveals that the HER2+ tumors are clearly visualized, whereas the signals from HER2- tumors are much lower. HER2-positive tumor uptake of ${ }^{99 \mathrm{~m}} \mathrm{Tc}-\mathrm{HYNIC}-\mathrm{H} 6 \mathrm{~F}$ and ${ }^{99 \mathrm{~m}} \mathrm{Tc}-\mathrm{HYNIC}-\mathrm{H} 10 \mathrm{~F}$ can be blocked by excess unlabeled $\mathrm{H} 6 \mathrm{~F}$ and $\mathrm{H} 10 \mathrm{~F}$ but not by excess trastuzumab. In the preliminary clinical study, the ${ }^{99 \mathrm{~m}}$ Tc-HYNIC-H10F has shown potential applications on non-invasive tumor classification, as well as prediction and monitoring of trastuzumab therapeutic efficacy.

Furthermore, Wang et al. [85] have designed a retro-inverso D-peptide of H6 (RDH6) to increase the metabolic stability and added PEGylation to improve its water solubility and in vivo pharmacokinetics. The results show that the D-amino acids ${ }^{99} \mathrm{~m}$ Tc-PEG4RDH6 bring better metabolic stability compared with ${ }^{99 \mathrm{~m}} \mathrm{Tc}-\mathrm{PEG} 4-\mathrm{H} 6$ with higher tumor uptake. In addition, the introduction of PEG can effectively increase tumor uptake, among which ${ }^{99 \mathrm{~m}}$ Tc-PEG24-RDH6 has a comparable tumor uptake and the lowest liver radioactivity. The SPECT imaging demonstrates that ${ }^{99 m}$ Tc-PEG24-RDH6 can specifically distinguish HER2-positive tumors from HER2-negative tumors with better imaging contrast, indicating that the ${ }^{99 \mathrm{~m}}$ Tc-PEG24-RDH6 has the potential for clinical screening of HER2-positive BC.

\subsection{Other Peptides}

Other potential peptides are also promising for the development of HER2 imaging agents. A9 peptide [86] is synthesized based on the design of trastuzumab (Fab) fragment, and it is synthesized with the chelator DTPA for labeling with ${ }^{111}$ In. The BT474 cell-binding experiment has revealed the presence of two ligand-binding sites on the receptor target, one with an affinity of $\mathrm{K}_{\mathrm{d}}=4.9 \mathrm{nM}$ and the other one with a weaker affinity $\left(\mathrm{K}_{\mathrm{d}}=103 \mathrm{nM}\right)$. This finding shows that more work is warranted for the A9 peptide in future studies.

\section{Conclusions and Outlook}

As a broad tumor biomarker, HER2 plays an important role in tumorigenesis. Therefore, accurate assessment of HER2 expression in cancer patients is essential for cancer diagnosis and treatment. Several different anti-HER2 probes, such as monoclonal antibodies, antibody fragments, Affibody molecules, and nanobodies, developed for both SPECT and PET have successfully reached the clinical setting for assessing whole-body HER2 expression patterns (Table 6). Although mAb molecular probes can identify HER2-positive lesions, slow blood clearance, low sensitivity, terrible tumor specificity, and non-specific uptake are still the main problems that limit its clinical transformation. HER2 imaging based on Fab and (Fab')2 fragments shows good imaging capabilities within $24 \mathrm{~h}$ after injection and can solve the issue of long waiting time between the injection of intact radiolabeled antibodies and imaging. However, it must be noted that the tumor uptake of $\left(\mathrm{Fab}^{\prime}\right) 2$ fragment is lower than the peak uptake of the parental antibody. Preclinical and clinical studies of small molecular probes, such as nanobodies and affibodies, have shown that they may be the most promising imaging agents. Their high affinity, specific targeting, and rapid clearance rate make it possible for them to evaluate the intertumoral expression heterogeneity and alteration of HER2 status during the disease. However, they still have the problems of high liver and kidney background, high cost, and may not be suitable for the evaluation of HER2-positive primary lesions.

In recent years, more and more small molecule peptides have been developed for HER2 imaging. The HER2-targeted peptides have shown strong potential for imaging HER2-positive tumors. The benefit for the development of these peptides includes the potentially quicker circulation time, deeper tissue penetration, non-immunogenicity, and ease of preparation. However, low tumor uptake levels and tumor-to-organ ratios are still the main problems to be solved in the development of short radiolabeled peptides. One of the main reasons is that the binding affinity of peptides is generally low. Therefore, more research on radiolabeled peptides is required to promote its clinical transformation.

At present, it is hard to say which type of HER2 tracer will be preferred in the clinical setting. We propose that the practical purpose of HER2 imaging will dictate the choice of 
imaging molecular probes. For instance, low molecular weight probes can be used as an alternative IHC or FISH to diagnose HER2 expression levels in tumors. In contrast, mAbs may be preferred for evaluating the efficacy of a monoclonal antibody-based therapy (e.g., trastuzumab, T-DM1, pertuzumab).

Table 6. The advantages and shortcomings of different types of molecular probes.

\begin{tabular}{ccc}
\hline Molecular Probes & Advantage & Shortcoming \\
\hline Monoclonal antibodies & Identify HER2-positive lesions & $\begin{array}{c}\text { Low blood clearance, low sensitivity, terrible tumor } \\
\text { specificity, and non-specific uptake, higher } \\
\text { radiation dose }\end{array}$ \\
\hline Antibody fragments & Imaging capabilities within 24 h & Low tumor uptake, low lesion detection rate \\
\hline Nanobodies & $\begin{array}{c}\text { Low molecular weight, high stability, nanomole } \\
\text { level affinity, better tumor penetration }\end{array}$ & $\begin{array}{c}\text { Higher kidney background, unsuitable for } \\
\text { evaluation of her2-positive primary breast lesions }\end{array}$ \\
\hline Affibodies & $\begin{array}{c}\text { Different binding sites from monoclonal } \\
\text { antibodies, picomole level affinity }\end{array}$ & Higher liver and kidney background \\
\hline Peptides & $\begin{array}{c}\text { Potentially quicker circulation time, deeper } \\
\text { tissue penetration, non-immunogenicity, ease } \\
\text { of preparation }\end{array}$ & Low tumor uptake and tumor-to-organ ratios \\
\hline
\end{tabular}

Based on existing preclinical and clinical studies, we are optimistic that HER2-targeted imaging can provide a non-invasive, dynamic visualization and quantification of HER2 expression status in heterogeneous tumors, which will improve the clinical management of HER2-targeted therapy.

Author Contributions: Conceptualization, S.D.; Literature research, S.G., J.L. and Y.Y. (Yu Yu); Writing—original draft preparation, S.G., J.L. and Y.Y. (Yu Yu); Writing—review and editing, S.G., J.L., Y.Y. (Yu Yu), Z.C., Y.Y. (Yi Yang), L.Z., S.S. and S.D. All authors have read and agreed to the published version of the manuscript.

Funding: This research was funded by the National Natural Science Foundation of China (grant no. 81601522), Medical Youth Talent Project of Jiangsu Province (grant no. QNRC2016749), Gusu Health Talent Program (grant no. GSWS2020013), Suzhou People's Livelihood Science and Technology Project (grant no. SYS2019038), Project of State Key Laboratory of Radiation Medicine and Protection, Soochow University (No. GZK1202127) and the open Foundation of Nuclear Medicine Laboratory of Mianyang Central Hospital, (No. 2021HYX023, 2021HYX026 and 2021HYX029).

Institutional Review Board Statement: Not Applicable.

Informed Consent Statement: Not Applicable.

Data Availability Statement: Not Applicable.

Conflicts of Interest: The authors declare no conflict of interest.

Sample Availability: Samples of the compounds are not available from the authors.

\section{References}

1. Sung, H.; Ferlay, J.; Siegel, R.L.; Laversanne, M.; Soerjomataram, I.; Jemal, A.; Bray, F. Global cancer statistics 2020: GLOBOCAN Estimates of incidence and mortality worldwide for 36 cancers in 185 countries. CA Cancer J. Clin. 2021, 71, 209-249. [CrossRef]

2. Fragomeni, S.M.; Sciallis, A.; Jeruss, J.S. Molecular subtypes and local-regional control of breast cancer. Surg. Oncol. Clin. N. Am. 2018, 27, 95-120. [CrossRef] [PubMed]

3. Loibl, S.; Poortmans, P.; Morrow, M.; Denkert, C.; Curigliano, G. Breast cancer. Lancet 2021, 397, 1750-1769. [CrossRef]

4. Perou, C.M.; Sorlie, T.; Eisen, M.B.; van de Rijn, M.; Jeffrey, S.S.; Rees, C.A.; Pollack, J.R.; Ross, D.T.; Johnsen, H.; Akslen, L.A.; et al. Molecular portraits of human breast tumours. Nature 2000, 406, 747-752. [CrossRef]

5. Denkert, C.; Liedtke, C.; Tutt, A.; von Minckwitz, G. Molecular alterations in triple-negative breast cancer-the road to new treatment strategies. Lancet 2017, 389, 2430-2442. [CrossRef] 
6. Hanna, W.M.; Slodkowska, E.; Lu, F.I.; Nafisi, H.; Nofech-Mozes, S. Comparative analysis of human epidermal growth factor receptor 2 testing in breast cancer according to 2007 and 2013 american society of clinical oncology/college of American pathologists guideline recommendations. J. Clin. Oncol. 2017, 35, 3039-3045. [CrossRef] [PubMed]

7. Slamon, D.J.; Clark, G.M.; Wong, S.G.; Levin, W.J.; Ullrich, A.; McGuire, W.L. Human breast cancer: Correlation of relapse and survival with amplification of the HER-2/neu oncogene. Science 1987, 235, 177-182. [CrossRef] [PubMed]

8. Press, M.F.; Bernstein, L.; Thomas, P.A.; Meisner, L.F.; Zhou, J.Y.; Ma, Y.; Hung, G.; Robinson, R.A.; Harris, C.; El-Naggar, A.; et al. HER-2/neu gene amplification characterized by fluorescence in situ hybridization: Poor prognosis in node-negative breast carcinomas. J. Clin. Oncol. 1997, 15, 2894-2904. [CrossRef] [PubMed]

9. Lu, J.; Steeg, P.S.; Price, J.E.; Krishnamurthy, S.; Mani, S.A.; Reuben, J.; Cristofanilli, M.; Dontu, G.; Bidaut, L.; Valero, V.; et al. Breast cancer metastasis: Challenges and opportunities. Cancer Res. 2009, 69, 4951-4953. [CrossRef] [PubMed]

10. Oh, D.Y.; Bang, Y.J. HER2-targeted therapies-A role beyond breast cancer. Nat. Rev. Clin. Oncol. 2020, 17, 33-48. [CrossRef] [PubMed]

11. Santinelli, A.; Pisa, E.; Stramazzotti, D.; Fabris, G. HER-2 status discrepancy between primary breast cancer and metastatic sites. Impact on target therapy. Int. J. Cancer 2008, 122, 999-1004. [CrossRef]

12. Ligthart, S.T.; Bidard, F.C.; Decraene, C.; Bachelot, T.; Delaloge, S.; Brain, E.; Campone, M.; Viens, P.; Pierga, J.Y.; Terstappen, L.W. Unbiased quantitative assessment of Her-2 expression of circulating tumor cells in patients with metastatic and non-metastatic breast cancer. Ann. Oncol. 2013, 24, 1231-1238. [CrossRef] [PubMed]

13. Schrijver, W.A.M.E.; Suijkerbuijk, K.P.M.; van Gils, C.H.; van der Wall, E.; Moelans, C.B.; van Diest, P.J. Receptor conversion in distant breast cancer metastases: A systematic review and meta-analysis. J. Natl. Cancer Inst. 2018, 110, 568-580. [CrossRef]

14. Niikura, N.; Liu, J.; Hayashi, N.; Mittendorf, E.A.; Gong, Y.; Palla, S.L.; Tokuda, Y.; Gonzalez-Angulo, A.M.; Hortobagyi, G.N.; Ueno, N.T. Loss of human epidermal growth factor receptor 2 (HER2) expression in metastatic sites of HER2-overexpressing primary breast tumors. J. Clin. Oncol. 2012, 30, 593-599. [CrossRef]

15. Van Poznak, C.; Somerfield, M.R.; Bast, R.C.; Cristofanilli, M.; Goetz, M.P.; Gonzalez-Angulo, A.M.; Hicks, D.G.; Hill, E.G.; Liu, M.C.; Lucas, W.; et al. Use of biomarkers to guide decisions on systemic therapy for women with metastatic breast cancer: American society of clinical oncology clinical practice guideline. J. Clin. Oncol. 2015, 33, 2695-2704. [CrossRef]

16. Tolmachev, V. Imaging of HER-2 overexpression in tumors for guiding therapy. Curr. Pharm. Des. 2008, 14, 2999-3019. [CrossRef] [PubMed]

17. Zhou, N.; Liu, C.; Guo, X.; Xu, Y.; Gong, J.; Qi, C.; Zhang, X.; Yang, M.; Zhu, H.; Shen, L.; et al. Impact of ${ }^{68}$ Ga-NOTA-MALMZHER2 PET imaging in advanced gastric cancer patients and therapeutic response monitoring. Eur. J. Nucl. Med. Mol. Imaging 2021, 48, 161-175. [CrossRef]

18. Mankoff, D.A.; Edmonds, C.E.; Farwell, M.D.; Pryma, D.A. Development of companion diagnostics. Semin. Nucl. Med. 2016, 46, 47-56. [CrossRef] [PubMed]

19. Massicano, A.V.F.; Marquez-Nostra, B.V.; Lapi, S.E. Targeting HER2 in nuclear medicine for imaging and therapy. Mol. Imaging 2018, 17, 1536012117745386. [CrossRef]

20. Zanzonico, P. Principles of nuclear medicine imaging: Planar, SPECT, PET, multi-modality, and autoradiography systems. Radiat. Res. 2012, 177, 349-364. [CrossRef] [PubMed]

21. Rahmim, A.; Zaidi, H. PET versus SPECT: Strengths, limitations and challenges. Nucl. Med. Commun. 2008, 29, 193-207. [CrossRef]

22. Perik, P.J.; Lub-De Hooge, M.N.; Gietema, J.A.; van der Graaf, W.T.; de Korte, M.A.; Jonkman, S.; Kosterink, J.G.; van Veldhuisen, D.J.; Sleijfer, D.T.; Jager, P.L.; et al. Indium-111-labeled trastuzumab scintigraphy in patients with human epidermal growth factor receptor 2-positive metastatic breast cancer. J. Clin. Oncol. 2006, 24, 2276-2282. [CrossRef] [PubMed]

23. Guo, X.; Zhou, N.; Chen, Z.; Liu, T.; Xu, X.; Lei, X.; Shen, L.; Gao, J.; Yang, Z.; Zhu, H. Construction of ${ }^{124}$ I-trastuzumab for noninvasive PET imaging of HER2 expression: From patient-derived xenograft models to gastric cancer patients. Gastric Cancer 2020, 23, 614-626. [CrossRef] [PubMed]

24. Tamura, K.; Kurihara, H.; Yonemori, K.; Tsuda, H.; Suzuki, J.; Kono, Y.; Honda, N.; Kodaira, M.; Yamamoto, H.; Yunokawa, M.; et al. 64Cu-DOTA-trastuzumab PET imaging in patients with HER2-positive breast cancer. J. Nucl. Med. 2013, 54, 1869-1875. [CrossRef]

25. Dijkers, E.C.; Kosterink, J.G.; Rademaker, A.P.; Perk, L.R.; van Dongen, G.A.; Bart, J.; de Jong, J.R.; de Vries, E.G.; Lub-de Hooge, M.N. Development and characterization of clinical-grade ${ }^{89} \mathrm{Zr}$-trastuzumab for HER2/neu immunoPET imaging. J. Nucl. Med. 2009, 50, 974-981. [CrossRef]

26. Behr, T.M.; Béhé, M.; Wörmann, B. Trastuzumab and breast cancer. N. Engl. J. Med. 2001, 345, $995-996$.

27. Ulaner, G.A.; Hyman, D.M.; Ross, D.S.; Corben, A.; Chandarlapaty, S.; Goldfarb, S.; McArthur, H.; Erinjeri, J.P.; Solomon, S.B.; Kolb, H.; et al. Detection of HER2-positive metastases in patients with HER2-negative primary breast cancer using 89Zr-Trastuzumab PET/CT. J. Nucl. Med. 2016, 57, 1523-1528. [CrossRef] [PubMed]

28. Ulaner, G.A.; Hyman, D.M.; Lyashchenko, S.K.; Lewis, J.S.; Carrasquillo, J.A. 89Zr-Trastuzumab PET/CT for detection of human epidermal growth factor receptor 2-positive metastases in patients with human epidermal growth factor receptor 2-negative primary breast cancer. Clin. Nucl. Med. 2017, 42, 912-917. [CrossRef] 
29. O’Donoghue, J.A.; Lewis, J.S.; Pandit-Taskar, N.; Fleming, S.E.; Schöder, H.; Larson, S.M.; Beylergil, V.; Ruan, S.; Lyashchenko, S.K.; Zanzonico, P.B.; et al. Pharmacokinetics, biodistribution, and radiation dosimetry for ${ }^{89} \mathrm{Zr}$-trastuzumab in patients with esophagogastric cancer. J. Nucl. Med. 2018, 59, 161-166. [CrossRef]

30. Bensch, F.; Brouwers, A.H.; Lub-de Hooge, M.N.; de Jong, J.R.; van der Vegt, B.; Sleijfer, S.; de Vries, E.G.E.; Schröder, C.P. ${ }^{89} \mathrm{Zr}$-trastuzumab PET supports clinical decision making in breast cancer patients, when HER2 status cannot be determined by standard work up. Eur. J. Nucl. Med. Mol. Imaging 2018, 45, 2300-2306. [CrossRef]

31. Gebhart, G.; Lamberts, L.E.; Wimana, Z.; Garcia, C.; Emonts, P.; Ameye, L.; Stroobants, S.; Huizing, M.; Aftimos, P.; Tol, J.; et al. Molecular imaging as a tool to investigate heterogeneity of advanced HER2-positive breast cancer and to predict patient outcome under trastuzumab emtansine (T-DM1): The ZEPHIR trial. Ann. Oncol. 2016, 27, 619-624. [CrossRef]

32. Mortimer, J.E.; Bading, J.R.; Park, J.M.; Frankel, P.H.; Carroll, M.I.; Tran, T.T.; Poku, E.K.; Rockne, R.C.; Raubitschek, A.A.; Shively, J.E.; et al. Tumor Uptake of ${ }^{64} \mathrm{Cu}$-DOTA-trastuzumab in patients with metastatic breast cancer. J. Nucl. Med. 2018, 59, 38-43. [CrossRef]

33. Dijkers, E.C.; Oude Munnink, T.H.; Kosterink, J.G.; Brouwers, A.H.; Jager, P.L.; de Jong, J.R.; van Dongen, G.A.; Schröder, C.P.; Lub-de Hooge, M.N.; de Vries, E.G. Biodistribution of 89Zr-trastuzumab and PET imaging of HER2-positive lesions in patients with metastatic breast cancer. Clin. Pharmacol. Ther. 2010, 87, 586-592. [CrossRef]

34. Mortimer, J.E.; Bading, J.R.; Colcher, D.M.; Conti, P.S.; Frankel, P.H.; Carroll, M.I.; Tong, S.; Poku, E.; Miles, J.K.; Shively, J.E.; et al. Functional imaging of human epidermal growth factor receptor 2-positive metastatic breast cancer using (64)Cu-DOTAtrastuzumab PET. J. Nucl. Med. 2014, 55, 23-29. [CrossRef]

35. Jiang, D.; Im, H.J.; Sun, H.; Valdovinos, H.F.; England, C.G.; Ehlerding, E.B.; Nickles, R.J.; Lee, D.S.; Cho, S.Y.; Huang, P.; et al. Radiolabeled pertuzumab for imaging of human epidermal growth factor receptor 2 expression in ovarian cancer. Eur. J. Nucl. Med. Mol. Imaging 2017, 44, 1296-1305. [CrossRef]

36. Ulaner, G.A.; Carrasquillo, J.A.; Riedl, C.C.; Yeh, R.; Hatzoglou, V.; Ross, D.S.; Jhaveri, K.; Chandarlapaty, S.; Hyman, D.M.; Zeglis, B.M.; et al. Identification of HER2-positive metastases in patients with HER2-negative primary breast cancer by using HER2-targeted ${ }^{89}$ Zr-pertuzumab PET/CT. Radiology 2020, 296, 370-378. [CrossRef]

37. Ulaner, G.A.; Lyashchenko, S.K.; Riedl, C.; Ruan, S.; Zanzonico, P.B.; Lake, D.; Jhaveri, K.; Zeglis, B.; Lewis, J.S.; O'Donoghue, J.A First-in-human human epidermal growth factor receptor 2-targeted imaging using ${ }^{89} \mathrm{Zr}$-Pertuzumab PET/CT: Dosimetry and clinical application in patients with breast cancer. J. Nucl. Med. 2018, 59, 900-906. [CrossRef] [PubMed]

38. Persson, M.; Tolmachev, V.; Andersson, K.; Gedda, L.; Sandström, M.; Carlsson, J. [(177)Lu]pertuzumab: Experimental studies on targeting of HER-2 positive tumour cells. Eur. J. Nucl. Med. Mol. Imaging 2005, 32, 1457-1462. [CrossRef]

39. McLarty, K.; Cornelissen, B.; Cai, Z.; Scollard, D.A.; Costantini, D.L.; Done, S.J.; Reilly, R.M. Micro-SPECT/CT with 111In-DTPApertuzumab sensitively detects trastuzumab-mediated HER2 downregulation and tumor response in athymic mice bearing MDA-MB-361 human breast cancer xenografts. J. Nucl. Med. 2009, 50, 1340-1348. [CrossRef] [PubMed]

40. Marquez, B.V.; Ikotun, O.F.; Zheleznyak, A.; Wright, B.; Hari-Raj, A.; Pierce, R.A.; Lapi, S.E. Evaluation of (89)Zr-pertuzumab in Breast cancer xenografts. Mol. Pharm. 2014, 11, 3988-3995. [CrossRef]

41. Smith-Jones, P.M.; Solit, D.B.; Akhurst, T.; Afroze, F.; Rosen, N.; Larson, S.M. Imaging the pharmacodynamics of HER2 degradation in response to Hsp90 inhibitors. Nat. Biotechnol. 2004, 22, 701-706. [CrossRef] [PubMed]

42. Oude Munnink, T.H.; de Vries, E.G.; Vedelaar, S.R.; Timmer-Bosscha, H.; Schröder, C.P.; Brouwers, A.H.; Lub-de Hooge, M.N. Lapatinib and 17AAG reduce 89Zr-trastuzumab-F(ab')2 uptake in SKBR3 tumor xenografts. Mol. Pharm. 2012, 9, $2995-3002$. [CrossRef] [PubMed]

43. Lam, K.; Chan, C.; Reilly, R.M. Development and preclinical studies of ${ }^{64} \mathrm{Cu}-\mathrm{NOTA}$-pertuzumab $\mathrm{F}\left(\mathrm{ab}^{\prime}\right)_{2}$ for imaging changes in tumor HER2 expression associated with response to trastuzumab by PET/CT. MAbs 2017, 9, 154-164. [CrossRef] [PubMed]

44. Beylergil, V.; Morris, P.G.; Smith-Jones, P.M.; Modi, S.; Solit, D.; Hudis, C.A.; Lu, Y.; O’Donoghue, J.; Lyashchenko, S.K.; Carrasquillo, J.A.; et al. Pilot study of 68Ga-DOTA-F(ab')2-trastuzumab in patients with breast cancer. Nucl. Med. Commun. 2013, 34, 1157-1165. [CrossRef] [PubMed]

45. Debie, P.; Lafont, C.; Defrise, M.; Hansen, I.; van Willigen, D.M.; van Leeuwen, F.W.B.; Gijsbers, R.; D’Huyvetter, M.; Devoogdt, N.; Lahoutte, T.; et al. Size and affinity kinetics of nanobodies influence targeting and penetration of solid tumours. J. Control. Release 2020, 317, 34-42. [CrossRef] [PubMed]

46. Xavier, C.; Vaneycken, I.; D’huyvetter, M.; Heemskerk, J.; Keyaerts, M.; Vincke, C.; Devoogdt, N.; Muyldermans, S.; Lahoutte, T.; Caveliers, V. Synthesis, preclinical validation, dosimetry, and toxicity of 68Ga-NOTA-anti-HER2 Nanobodies for iPET imaging of HER2 receptor expression in cancer. J. Nucl. Med. 2013, 54, 776-784. [CrossRef]

47. Keyaerts, M.; Xavier, C.; Heemskerk, J.; Devoogdt, N.; Everaert, H.; Ackaert, C.; Vanhoeij, M.; Duhoux, F.P.; Gevaert, T.; Simon, P.; et al. Phase I Study of 68Ga-HER2-Nanobody for PET/CT assessment of HER2 expression in breast carcinoma. J. Nucl. Med. 2016, 57, 27-33. [CrossRef] [PubMed]

48. Vaneycken, I.; Devoogdt, N.; Van Gassen, N.; Vincke, C.; Xavier, C.; Wernery, U.; Muyldermans, S.; Lahoutte, T.; Caveliers, V. Preclinical screening of anti-HER2 nanobodies for molecular imaging of breast cancer. FASEB J. 2011, 25, 2433-2446. [CrossRef]

49. Zhou, Z.; Chitneni, S.K.; Devoogdt, N.; Zalutsky, M.R.; Vaidyanathan, G. Fluorine-18 labeling of an anti-HER2 VHH using a residualizing prosthetic group via a strain-promoted click reaction: Chemistry and preliminary evaluation. Bioorg. Med. Chem. 2018, 26, 1939-1949. [CrossRef] [PubMed] 
50. Zhou, Z.; McDougald, D.; Devoogdt, N.; Zalutsky, M.R.; Vaidyanathan, G. Labeling single domain antibody fragments with fluorine-18 using 2,3,5,6-tetrafluorophenyl 6-[ $\left.{ }^{18} \mathrm{~F}\right]$ Fluoronicotinate resulting in high tumor-to-kidney ratios. Mol. Pharm. 2019, 16, 214-226. [CrossRef] [PubMed]

51. D’Huyvetter, M.; De Vos, J.; Xavier, C.; Pruszynski, M.; Sterckx, Y.G.J.; Massa, S.; Raes, G.; Caveliers, V.; Zalutsky, M.R.; Lahoutte, T.; et al. ${ }^{131}$ I-labeled Anti-HER2 Camelid sdAb as a theranostic tool in cancer treatment. Clin. Cancer Res. 2017, 23, 6616-6628. [CrossRef]

52. D'Huyvetter, M.; Vincke, C.; Xavier, C.; Aerts, A.; Impens, N.; Baatout, S.; De Raeve, H.; Muyldermans, S.; Caveliers, V.; Devoogdt, N.; et al. Targeted radionuclide therapy with A 177Lu-labeled anti-HER2 nanobody. Theranostics 2014, 4, 708-720. [CrossRef]

53. Lee, H.; Shields, A.F.; Siegel, B.A.; Miller, K.D.; Krop, I.; Ma, C.X.; LoRusso, P.M.; Munster, P.N.; Campbell, K.; Gaddy, D.F.; et al. ${ }^{64} \mathrm{Cu}-\mathrm{MM}-302$ positron emission tomography quantifies variability of enhanced permeability and retention of nanoparticles in relation to treatment response in patients with metastatic breast cancer. Clin. Cancer Res. 2017, 23, 4190-4202. [CrossRef]

54. Ståhl, S.; Gräslund, T.; Eriksson Karlström, A.; Frejd, F.Y.; Nygren, P.Å.; Löfblom, J. Affibody molecules in biotechnological and medical applications. Trends. Biotechnol. 2017, 35, 691-712. [CrossRef] [PubMed]

55. Tolmachev, V.; Orlova, A.; Nilsson, F.Y.; Feldwisch, J.; Wennborg, A.; Abrahmsén, L. Affibody molecules: Potential for in vivo imaging of molecular targets for cancer therapy. Expert. Opin. Biol. Ther. 2007, 7, 555-568. [CrossRef] [PubMed]

56. Tolmachev, V.; Nilsson, F.Y.; Widström, C.; Andersson, K.; Rosik, D.; Gedda, L.; Wennborg, A.; Orlova, A. 111In-benzyl-DTPAZHER2:342, an affibody-based conjugate for in vivo imaging of HER2 expression in malignant tumors. J. Nucl. Med. 2006, 47, 846-853.

57. Kramer-Marek, G.; Bernardo, M.; Kiesewetter, D.O.; Bagci, U.; Kuban, M.; Aras, O.; Zielinski, R.; Seidel, J.; Choyke, P.; Capala, J. PET of HER2-positive pulmonary metastases with 18F-ZHER2:342 affibody in a murine model of breast cancer: Comparison with 18F-FDG. J. Nucl. Med. 2012, 53, 939-946. [CrossRef] [PubMed]

58. Honarvar, H.; Westerlund, K.; Altai, M.; Sandström, M.; Orlova, A.; Tolmachev, V.; Karlström, A.E. Feasibility of affibody molecule-based PNA-mediated radionuclide pretargeting of malignant tumors. Theranostics 2016, 6, 93-103. [CrossRef]

59. Baum, R.P.; Prasad, V.; Müller, D.; Schuchardt, C.; Orlova, A.; Wennborg, A.; Tolmachev, V.; Feldwisch, J. Molecular imaging of HER2-expressing malignant tumors in breast cancer patients using synthetic 111In- or 68Ga-labeled affibody molecules. J. Nucl. Med. 2010, 51, 892-897. [CrossRef] [PubMed]

60. Sörensen, J.; Sandberg, D.; Sandström, M.; Wennborg, A.; Feldwisch, J.; Tolmachev, V.; Åström, G.; Lubberink, M.; GarskeRomán, U.; Carlsson, J.; et al. First-in-human molecular imaging of HER2 expression in breast cancer metastases using the 111In-ABY-025 affibody molecule. J. Nucl. Med. 2014, 55, 730-735. [CrossRef] [PubMed]

61. Sandström, M.; Lindskog, K.; Velikyan, I.; Wennborg, A.; Feldwisch, J.; Sandberg, D.; Tolmachev, V.; Orlova, A.; Sörensen, J.; Carlsson, J.; et al. Biodistribution and radiation dosimetry of the Anti-HER2 affibody molecule 68Ga-ABY-025 in breast cancer patients. J. Nucl. Med. 2016, 57, 867-871. [CrossRef]

62. Sörensen, J.; Velikyan, I.; Sandberg, D.; Wennborg, A.; Feldwisch, J.; Tolmachev, V.; Orlova, A.; Sandström, M.; Lubberink, M.; Olofsson, H.; et al. Measuring HER2-receptor expression in metastatic breast cancer using [68Ga]ABY-025 Affibody PET/CT. Theranostics 2016, 6, 262-271. [CrossRef] [PubMed]

63. Glaser, M.; Iveson, P.; Hoppmann, S.; Indrevoll, B.; Wilson, A.; Arukwe, J.; Danikas, A.; Bhalla, R.; Hiscock, D. Three methods for 18F labeling of the HER2-binding affibody molecule Z(HER2:2891) including preclinical assessment. J. Nucl. Med. 2013, 54, 1981-1988. [CrossRef]

64. Trousil, S.; Hoppmann, S.; Nguyen, Q.D.; Kaliszczak, M.; Tomasi, G.; Iveson, P.; Hiscock, D.; Aboagye, E.O. Positron emission tomography imaging with 18F-labeled ZHER2:2891 affibody for detection of HER2 expression and pharmacodynamic response to HER2-modulating therapies. Clin. Cancer Res. 2014, 20, 1632-1643. [CrossRef]

65. Garousi, J.; Lindbo, S.; Nilvebrant, J.; Åstrand, M.; Buijs, J.; Sandström, M.; Honarvar, H.; Orlova, A.; Tolmachev, V.; Hober, S. ADAPT, a novel scaffold protein-based probe for radionuclide imaging of molecular targets that are expressed in disseminated cancers. Cancer Res. 2015, 75, 4364-4371. [CrossRef] [PubMed]

66. Von Witting, E.; Garousi, J.; Lindbo, S.; Vorobyeva, A.; Altai, M.; Oroujeni, M.; Mitran, B.; Orlova, A.; Hober, S.; Tolmachev, V. Selection of the optimal macrocyclic chelators for labeling with ${ }^{111}$ In and ${ }^{68}$ Ga improves contrast of HER2 imaging using engineered scaffold protein ADAPT6. Eur. J. Pharm. Biopharm. 2019, 140, 109-120. [CrossRef] [PubMed]

67. Bragina, O.; von Witting, E.; Garousi, J.; Zelchan, R.; Sandström, M.; Orlova, A.; Medvedeva, A.; Doroshenko, A.; Vorobyeva, A.; Lindbo, S.; et al. Phase I Study of ${ }^{99 \mathrm{~m}}$ Tc-ADAPT6, a scaffold protein-based probe for visualization of HER2 expression in breast cancer. J. Nucl. Med. 2021, 62, 493-499. [CrossRef] [PubMed]

68. Fani, M.; Maecke, H.R.; Okarvi, S.M. Radiolabeled peptides: Valuable tools for the detection and treatment of cancer. Theranostics 2012, 2, 481-501. [CrossRef] [PubMed]

69. Fosgerau, K.; Hoffmann, T. Peptide therapeutics: Current status and future directions. Drug Discov. Today 2015, 20, 122-128. [CrossRef] [PubMed]

70. Karasseva, N.G.; Glinsky, V.V.; Chen, N.X.; Komatireddy, R.; Quinn, T.P. Identification and characterization of peptides that bind human ErbB-2 selected from a bacteriophage display library. J. Protein Chem. 2002, 21, 287-296. [CrossRef]

71. Kumar, S.R.; Gallazzi, F.A.; Ferdani, R.; Anderson, C.J.; Quinn, T.P.; Deutscher, S.L. In vitro and in vivo evaluation of ${ }^{64} \mathrm{Cu}-$ radiolabeled KCCYSL peptides for targeting epidermal growth factor receptor-2 in breast carcinomas. Cancer Biother. Radiopharm. 2010, 25, 693-703. [CrossRef] 
72. Larimer, B.M.; Thomas, W.D.; Smith, G.P.; Deutscher, S.L. Affinity maturation of an ERBB2-targeted SPECT imaging peptide by in vivo phage display. Mol. Imaging Biol. 2014, 16, 449-458. [CrossRef] [PubMed]

73. Shadidi, M.; Sioud, M. Identification of novel carrier peptides for the specific delivery of therapeutics into cancer cells. FASEB J. 2003, 17, 256-258. [CrossRef] [PubMed]

74. Shahsavari, S.; Shaghaghi, Z.; Abedi, S.M.; Hosseinimehr, S.J. Evaluation of ${ }^{99 \mathrm{~m}}$ Tc-HYNIC-(ser) ${ }_{3}$-LTVPWY peptide for glioblastoma imaging. Int. J. Radiat. Biol. 2020, 96, 502-509. [CrossRef]

75. Aligholikhamseh, N.; Ahmadpour, S.; Khodadust, F.; Abedi, S.M.; Hosseinimehr, S.J. ${ }^{99 m}$ Tc-HYNIC-(Ser)3-LTVPWY peptide bearing tricine as co-ligand for targeting and imaging of HER2 overexpression tumor. Radiochim. Acta 2018, 106, 601-609. [CrossRef]

76. Park, B.W.; Zhang, H.T.; Wu, C.; Berezov, A.; Zhang, X.; Dua, R.; Wang, Q.; Kao, G.; O'Rourke, D.M.; Greene, M.I.; et al. Rationally designed anti-HER2/neu peptide mimetic disables P185HER2/neu tyrosine kinases in vitro and in vivo. Nat. Biotechnol. 2000, 18, 194-198. [CrossRef] [PubMed]

77. Kumar, S.R.; Quinn, T.P.; Deutscher, S.L. Evaluation of an ${ }^{111}$ In-radiolabeled peptide as a targeting and imaging agent for ErbB-2 receptor expressing breast carcinomas. Clin. Cancer Res. 2007, 13, 6070-6079. [CrossRef]

78. Sabahnoo, H.; Noaparast, Z.; Abedi, S.M.; Hosseinimehr, S.J. New small ${ }^{99 \mathrm{~m}}$ Tc-labeled peptides for HER2 receptor imaging. Eur. J. Med. Chem. 2017, 127, 1012-1024. [CrossRef] [PubMed]

79. Khodadust, F.; Ahmadpour, S.; Aligholikhamseh, N.; Abedi, S.M.; Hosseinimehr, S.J. An improved ${ }^{99 m}{ }^{T c-H Y N I C-(S e r)}{ }_{3}{ }^{-}$ LTVSPWY peptide with EDDA/tricine as co-ligands for targeting and imaging of HER2 overexpression tumor. Eur. J. Med. Chem. 2018, 144, 767-773. [CrossRef] [PubMed]

80. Biabani Ardakani, J.; Akhlaghi, M.; Nikkholgh, B.; Hosseinimehr, S.J. Targeting and imaging of HER2 overexpression tumor with a new peptide-based ${ }^{68}$ Ga-PET radiotracer. Bioorg. Chem. 2021, 106, 104474. [CrossRef]

81. Guan, S.S.; Wu, C.T.; Chiu, C.Y.; Luo, T.Y.; Wu, J.Y.; Liao, T.Z.; Liu, S.H. Polyethylene glycol-conjugated HER2-targeted peptides as a nuclear imaging probe for HER2-overexpressed gastric cancer detection in vivo. J. Transl. Med. 2018, 16, 168. [CrossRef] [PubMed]

82. Li, L.; Wu, Y.; Wang, Z.; Jia, B.; Hu, Z.; Dong, C.; Wang, F. SPECT/CT Imaging of the Novel HER2-targeted peptide probe 99m Tc-HYNIC-H6F in breast cancer mouse models. J. Nucl. Med. 2017, 58, 821-826. [CrossRef] [PubMed]

83. Wu, Y.; Li, L.; Wang, Z.; Shi, J.; Hu, Z.; Gao, S.; Miao, W.; Ma, Q.; Dong, C.; Wang, F. Imaging and monitoring HER2 expression in breast cancer during trastuzumab therapy with a peptide probe ${ }^{99 m}$ Tc-HYNIC-H10F. Eur. J. Nucl. Med. Mol. Imaging 2020, 47, 2613-2623. [CrossRef] [PubMed]

84. Wang, Z.; Wang, W.; Bu, X.; Wei, Z.; Geng, L.; Wu, Y.; Dong, C.; Li, L.; Zhang, D.; Yang, S.; et al. Microarray based screening of peptide nano probes for HER2 positive tumor. Anal. Chem. 2015, 87, 8367-8372. [CrossRef] [PubMed]

85. Du, S.; Luo, C.; Yang, G.; Gao, H.; Wang, Y.; Li, X.; Zhao, H.; Luo, Q.; Ma, X.; Shi, J.; et al. Developing PEGylated reversed D-Peptide as a Novel HER2-targeted SPECT imaging probe for breast cancer detection. Bioconjug. Chem. 2020, 31, 1971-1980. [CrossRef] [PubMed]

86. Luca, S.; Verdoliva, V.; Saviano, M. Peptide ligands specifically targeting HER2 Receptor and the role played by a synthetic model system of the receptor extracellular domain: Hypothesized future perspectives. J. Med. Chem. 2020, 63, 15333-15343. [CrossRef] [PubMed] 